\title{
InSAR investigation of sackung-like features and debris flows in the vicinity of Hawkesbury Island and Hartley Bay, British Columbia, Canada
}

\author{
D Huntley Geological Survey of Canada, Canada \\ D Rotheram Geological Survey of Canada, Canada \\ P Bobrowsky Geological Survey of Canada, Canada \\ G Lintern Geological Survey of Canada, Canada \\ R MacLeod Geological Survey of Canada, Canada \\ C Brillon Geological Survey of Canada, Canada
}

\begin{abstract}
Future development in coastal northwest British Columbia requires safe, secure locations for infrastructure installations and communities. The challenge for managing environmental and infrastructure protection and site reclamation will be to accommodate future extreme weather events, climate change, and damage from earthquakes, landslides and tsunamis. New insights into the terrestrial and marine geohazards offered by our work will help reduce the future development risks to governments, resource industries, communities and the environment. SAR imagery captures two debris flow events in the vicinity of Hartley Bay that occurred between September 2017 and January 2018 during fall or winter storm events. SAR imagery also captures flooding in a nearby lake basin over this period. The extent to which the debris flows detected impacted local watersheds has yet to be determined by ground observations and public consultation. For Hawkesbury Island and the surrounding area, a provisional InSAR analysis suggests that on short time-scales (<2 years), the deep-seated, sackung-like bedrock fractures observed on the western flank are stable. These paraglacial features were likely formed by stress release during debuttressing of side walls, glacio-isostatic rebound, neo-tectonic faulting, and permafrost loss during deglaciation. This finding has implications for landslide and tsunami risk assessments, suggesting the stable western flank of Hawkesbury Island does not represent a geological hazard to fjord-bound communities, coastal infrastructure, and natural resource activities.
\end{abstract}

Keywords: InSAR, sackung, rapid rock slope failure, debris flow, tsunami, infrastructure, public safety, natural environment, geohazard

\section{Introduction}

Sustainable economic growth in Canada requires the construction, operation, and maintenance of resilient railways, pipelines, power transmission lines, highways, bridges, tunnels, and other supporting infrastructure linking coastal deep-water port facilities and global markets with the natural resource-endowed hinterland (Figure 1(a)). To help meet these demands, several multi-billion dollar infrastructure projects (e.g. pipelines, storage and shipping facilities) related to liquified natural gas (LNG) and diluted bitumen products (DILBIT) are proposed in the Douglas Channel fjord, northwestern British Columbia, encompassing the communities of Kitimat, Kitamaat and Hartley Bay: traditional lands of the Gitga'at and Haisla First Nations (Figure 1(b)).

A significant challenge to safe and secure coastal infrastructure and communities in northwestern British Columbia are recurrent landslides, storms, floods, earthquakes and rare tsunamis. The Geological Survey of Canada (GSC) has mandated responsibilities to investigate natural geohazards such as earthquakes, landslides, and tsunamis that have the potential to negatively impact critical infrastructure and vulnerable 
communities. These field-based and desktop investigations are used to help mitigate the impacts that such events may have on the health and safety of Canadians, socio-economic infrastructure, and the natural environment (Shaw \& Lintern 2016; Lintern et al. 2016; Lintern et al. 2018).

This paper focuses attention on debris flows in the vicinity of Hartley Bay (Blais-Stevens et al. 2016; Maynard et al. 2017), and deep-seated gravitational deformation features on the southwest flank of Hawkesbury Island, observed upslope of two previously recognised submarine block failures (Thomson et al. 2012; Conway \& Barrie 2015; Huntley et al. 2018; Figure 2). Failure of portions of the southwestern flank of Hawkesbury Island would generate significant displacement of water in the southern Douglas Channel (cf. Wieczorek et al. 2007; Thomson et al. 2012; Higman et al. 2018), with the potential to impact the village of Hartley Bay (Figure 4(d)), commercial shipping, fishing vessels and other watercraft operating in the fjord, and critical coastal infrastructure located elsewhere in the fjord (e.g. port and dock facilities at Kitimat \& Kitamaat). Satellite (RADARSAT-2) interferometric synthetic aperture radar (InSAR) was identified to provide the best opportunity to determine the extent of slope displacement of the fjord walls of Hawkesbury Island, Douglas Channel (cf. Journault et al. 2018). The results presented here will help determine the threshold size and volume for displaced sediment and bedrock masses to generate tsunamis sizeable enough to damage critical infrastructure and threaten public safety.
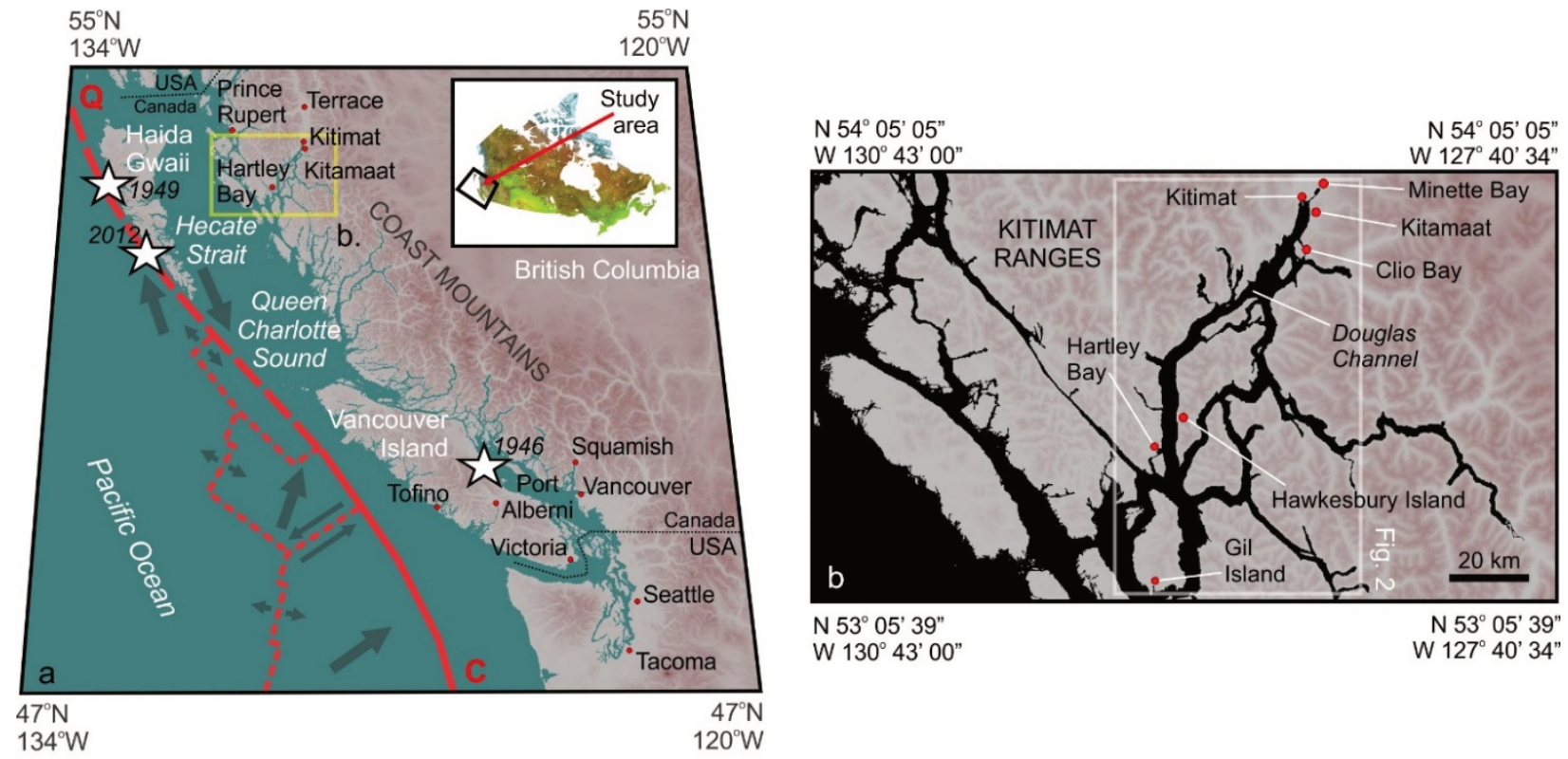

Figure 1 (a) Study area with major plate tectonic elements (after Rohr \& Tryon 2010 and Brillon 2016), significant earthquake epicentres (white stars), and locations of coastal communities with deepwater port facilities and First Nations settlements; (b) Location of field observations and sites discussed in text

\section{Geomorphic history and geohazards in the study area}

In 1974 and 1975 submarine slumps on Kitimat River delta front generated a series of tsunamis that damaged marine infrastructure under construction and residential properties in the nearby communities of Kitimat and Kitamaat (Lintern et al. 2018). Clastic deposits in tidal peat marshes and forest soils of Douglas Channel preserve evidence of these events, and older recurrent marine inundation events attributed to displacement waves triggered by landslides on steep coastal slopes, storm surge waves, flood events from glacierised Cordilleran watersheds, and great earthquake-generated tsunamis (Huntley et al. 2018).

The diverse physiography of coastal northwest British Columbia is a significant control on terrestrial and submarine geomorphological processes, and their resulting sediments and landforms (Shaw \& Lintern 2016; Shaw et al. 2016; Blais-Steven et al. 2016; Maynard et al. 2017). Outboard of the mainland, low-lying islands with reefs, coves, inlets, embayments, and rocky shorelines transition to steep mountainous terrain with 
relict alpine glacial landforms with peaks up to $500 \mathrm{~m}$ elevation. This archipelago flanks the Kitimat Ranges, part of the glacierised Coast Mountains, where glaciers remain in the headwaters of several drainage basins. Peaks flanking the Douglas Channel and other inlets comprising the Kitimat fjord system are generally rounded, with conformable summits between 1,000 and 1,350 m elevation (Clague 1984; Huntley et al. 2018). Douglas Channel is a drowned northeast-trending glaciated trough that dissects the Kitimat Ranges to depths in excess of 1000 m near Hawkesbury Island and Hartley Bay (Shaw \& Lintern 2016; Figure 1(b)). The wide range of deposits covering submerged and terrestrial portions of the fjord floor and side walls reflect numerous geomorphic processes operating during, and since glaciation (Figure 2). Geohazards are described in terms of magnitude and likelihood of occurrence over a range of time-scales.

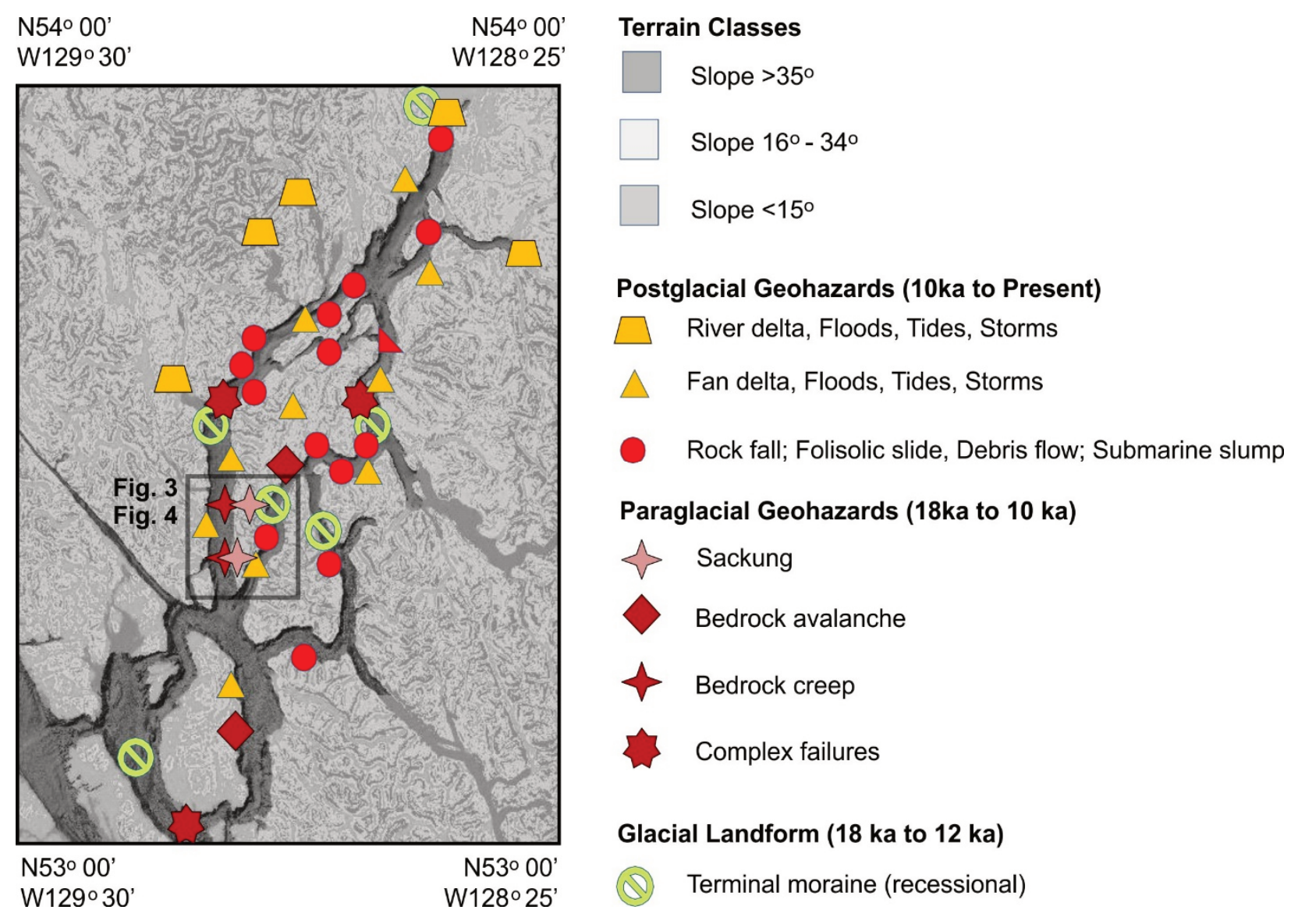

Figure 2 Geohazards of the Kitimat fjord: terrestrial, terrain slope classes in the Kitimat fjord watershed derived from shuttle radar topographic mapping 3-arc-second digital elevation model using Global Mapper software (Blue Marble Geographics 2020); distribution of glacial and postglacial geohazards combined multi-beam sonar imagery modified from Shaw \& Lintern (2016)

\subsection{Paraglacial geohazards}

At the last glacial maximum, mountain valley glaciers from the Kitimat Ranges were confluent with southwest-flowing ice streams occupying the Kitimat fjord and Skeena River valley. Piedmont lobes from these glacial troughs sometimes coalesced with southeast-flowing ice from Haida Gwaii over the Hecate Strait to form the northwestern sector of Cordilleran Ice Sheet (Barrie et al. 2014). Submerged diamicton-filled drumlin ridges up to $10 \mathrm{~m}$ high and $3 \mathrm{~km}$ long are confined to the outer limits of the Kitimat fjord, indicating glacial ice flow from Douglas Channel into Hecate Strait at the last glacial maximum (Shaw \& Lintern 2016; Shaw et al. 2016). These terrestrial subglacial features were drowned as sea levels rose at the onset of deglaciation. Radiocarbon dating indicates the largest mass-wasting events occurred during deglaciation as ice retreated from the Kitimat fjord (Conway \& Barrie 2015), and sea level change significantly altered the regional paleogeography. Terminal moraine deposits, comprising linear ridges up to $7 \mathrm{~km}$ long and $30 \mathrm{~m}$ high, lying transverse to the channel axis, are composed of thick deposits of glacial diamicton 
capped by glaciomarine fines. Smaller recessional lobate ridges around $100 \mathrm{~m}$ wide and 5-10 $\mathrm{m}$ high are also composed of glacial diamicton, coarsening to boulder-rich gravel at the sea floor. These landforms define stable grounding-line positions for retreating tidewater glaciers in the Douglas Channel (Figure 2).

Mud-rich gravel and sand draping glacial diamictons are indicative of rising sea level and the onset of glaciomarine conditions during ice retreat. On the rear slope of the submerged terminal moraine ridge $20 \mathrm{~km}$ north of Hartley Bay, a $15 \mathrm{~km}^{2}$ submarine failure with escarpments, gullies, depositional basins and irregular relief is evidence of slope instability and mass-wasting (Shaw \& Lintern 2016; Shaw et al. 2016). A similar (now subaerial) grounding-line moraine at Kitimat, graded to $135 \mathrm{~m}$ elevation, delimits the maximum limit of glaciomarine inundation of Kitimat fjord during deglaciation (Clague 1984, 1985; Barrie et al. 2014).

At elevations below the glaciomarine limit, terrestrial and submarine fjord sidewalls include steep $\left(>40^{\circ}\right)$, glacially scoured bedrock slopes, ridges and knolls separated by ledges and depressions containing glacial and postglacial sediments (Figure 2 ). Moderately steep sidewall slopes $\left(>10^{\circ}\right)$ are composed of glaciomarine sediment with a surface lag of postglacial gravel and sand-rich mud. These slopes are often incised by gullies up to $10 \mathrm{~m}$ deep. Where exposed on the fjord floor, glaciomarine deposits display iceberg furrows, pits and surface lags of gravel and sand-rich mud (i.e. silt and clay). Stratified mud, sand and gravel deposited from glacial meltwater plumes occur at deeper stratigraphic levels (Bornhold 1983; Shaw \& Lintern 2016; Shaw et al. 2016).

West of Hartley Bay, submerged bedrock blocks $1.2 \mathrm{~km}^{2}$ and $1.4 \mathrm{~km}^{2}$ in areal extent (volume estimate, $>60 \times 10^{6} \mathrm{~m}^{3}$ ), are detached from submerged fjord sidewalls of Hawkesbury Island. These deglaciation features, formed by unloading, stress relief and gravitational creep, are mantled by a veneer of gullied, undeformed postglacial marine sediments, suggesting failure occurred episodically between 13,400 and 15,800 years before present (Conway et al. 2012; Thomson et al. 2012; Lintern et al. 2016; Shaw \& Lintern 2016; Shaw et al. 2016; Conway \& Barrie 2018).

Above the glaciomarine limit, slope failures in deglaciated valleys were accompanied by glaciofluvial outburst floods, both conditioned by the proximity of receding ice margins and falling relative sea level during deglaciation. Sackung-like deep-seated fractures, or gravitational deformation structures (cf. Ambrosi \& Crosta 2006; Wieczorek et al. 2007) on the west side of Hawkesbury Island formed upslope of the two submarine bedrock blocks as fjord sidewalls and existing regional N-S oriented, dextral shear zones unloaded and relaxed during deglaciation (Huntley et al. 2018). Elsewhere, terrestrial rock avalanches from the flanks of Hawkesbury Island and Gil Island form submarine block fields up to $2 \mathrm{~km}^{2}$ in extent. These deposits are mantled by postglacial mud and sand, indicating that such events occurred prior to 8,000 years before present (Shaw \& Lintern 2016; Shaw et al. 2016; Figure 2).

\section{$2.2 \quad$ Postglacial geohazards}

Postglacial marine sediments in Douglas Channel form low relief (slopes $<10^{\circ}$ ) banks and sand-rich mud blankets $>50 \mathrm{~m}$ thick. These submarine stratified deposits are composed of reworked glacial diamicton and fluvial sediment (Shaw \& Lintern 2016; Shaw et al. 2016). Surface gravel lags and areas of scour and winnowing expose underlying glaciomarine sediments at the sea floor. More than 100 rivers, creeks and gullies drain into the fjord. A large postglacial delta has formed at the fjord head where Kitimat River enters Douglas Channel (Figure 2). Elsewhere, postglacial fan deltas at river and stream outflows form cone-shaped deposits banked against fjord sidewalls (Shaw \& Lintern 2016; Shaw et al. 2016). These features are traditional locations for First Nations settlements in the region, and archaeological sites of interest (e.g. Kitimat, Kitamaat and Hartley Bay).

Terrestrial mapping (Figure 3) and marine surveys have identified deposits indicative of numerous postglacial floods, storms, earthquakes, landslides, and submarine mass-wasting events in Douglas Channel and the network of passages through the archipelago (e.g. Luternauer \& Swan 1978; Prior et al. 1982; Clague 1984, 1985; Maynard et al. 2017; Huntley et al. 2018). In postglacial times, changes in the intensity and duration of decadal oscillations between warm and cool phases in the Pacific Ocean have influenced the magnitude and frequency of storm surges impacting coastal British Columbia (Tinis 2015). Currently, significant precipitation 
falls annually, and the region experiences high rates of snow pack melt during spring and summer months (Shaw \& Lintern 2016). Consequently, watersheds draining into the coves, bays, channels, and inlets are prone to frequent seasonal flooding (Septer \& Schwab 1995).

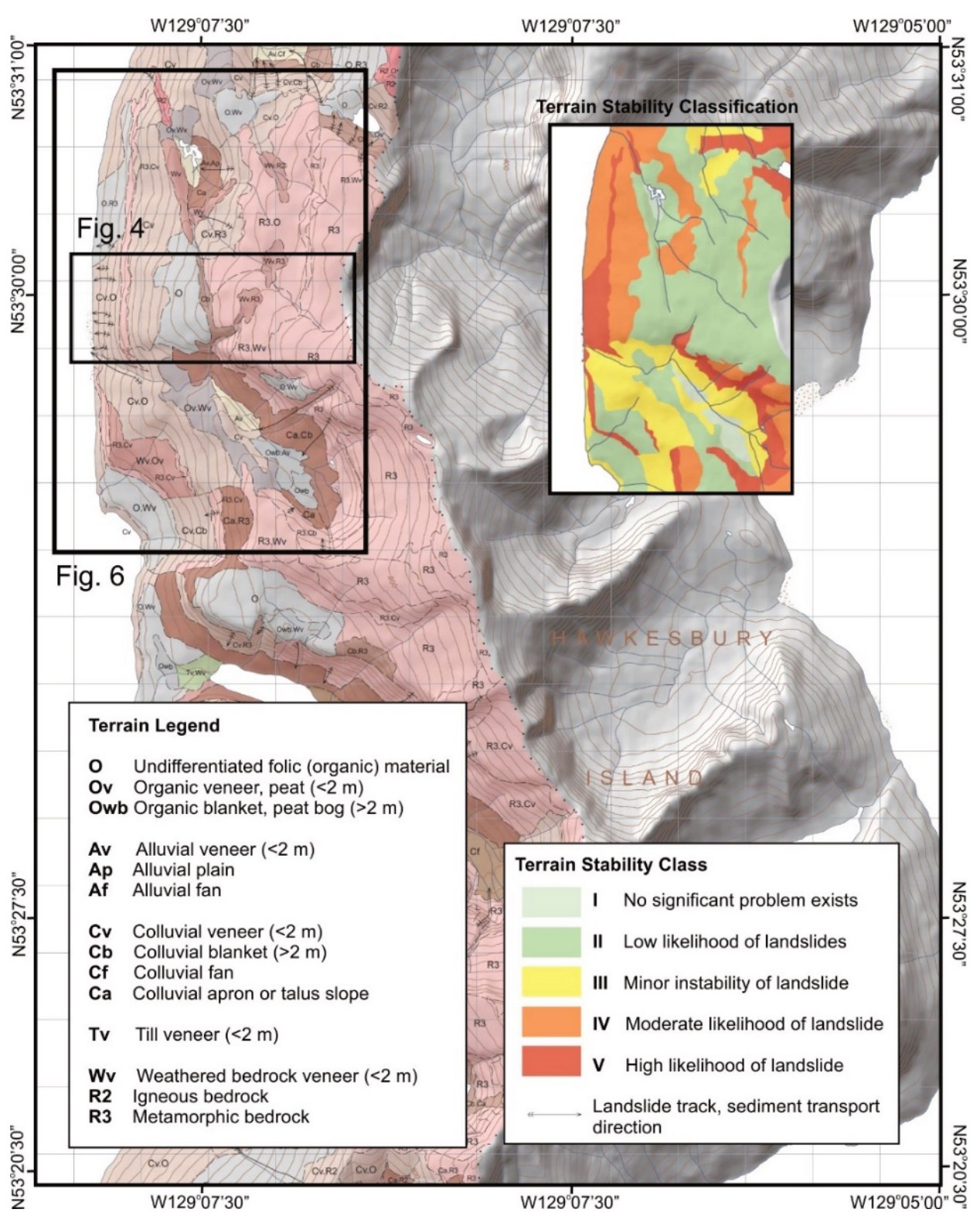

Figure 3 Surficial geology and terrain stability classification of southern Hawkesbury Island (modified from Blais-Stevens et al. 2016; Maynard et al. 2017)

Postglacial submarine debris slides and slumps of differing ages are formed by failure of stratified sediment on steep fjord sidewalls, fans and delta fronts (Figure 2). Submarine slumps vary in size from $0.2 \mathrm{~km}^{2}$ in Douglas Channel to $8.2 \mathrm{~km}^{2}$ on the Kitimat River delta front (Shaw \& Lintern 2016; Shaw et al. 2016). These features, less than $10 \mathrm{~m}$ thick, are composed of mud, sand, gravel and boulders buried to varying degrees by postglacial material. Triggering mechanisms include extreme tides, groundwater leaching, artesian flow and high rates of deltaic sedimentation (Luternauer \& Swan 1978; Murty 1979; Prior et al. 1982).

Numerical models support documented reports of displacement waves and damage generated from submarine slumps on the Kitimat River delta front in the mid-1970s (Golder Associates 1975). New evidence of tsunami deposits in Douglas Channel suggest that displacement waves generated by submarine slumps from the Kitimat River delta in 1974 and 1975 reached Minette Bay (6 km northeast) and Clio Bay (12 km 
south). The presence of older tsunami deposits in these bays is interpreted as evidence of past earthquake activity or large volume landslide events in Douglas Channel (Huntley et al. 2018).

On steep terrestrial bedrock slopes, elongated debris flows or slides smaller than $0.8 \mathrm{~km}^{2}$ remove vegetation and thin organic soil (Folisol) to the Douglas Channel (Figure 3). Folisolic slides and rockfalls form submarine talus cones, slumps and slide blocks seen in bottom profile surveys of the fjord (Shaw \& Lintern 2016; Blais-Stevens et al. 2016; Shaw et al. 2016; Maynard et al. 2017). These frequent, smaller volume events do not generate tsunamis of any consequence. In contrast, marine sediments deposited beyond storm berms in bays at the fjord head are a record of tsunamis generated locally by large landslides and marine slumps, or by more distant earthquakes.

The region is seismically active, with oblique convergence and transform motion occurring along the plate boundaries of the western continental margin, including Vancouver Island, Queen Charlotte Strait, and Haida Gwaii (Rohr \& Tryon 2010; Brillon 2016; Figure 1(a)). Over the last 100 years, numerous large earthquakes have occurred along faults in this seismic zone, including a magnitude 7.3 event in 1946 on Vancouver Island, and on Haida Gwaii, a magnitude 8.1 event in 1949, and most recently, a magnitude 7.8 event in 2012 (Figure 1(a)). Subduction triggered earthquakes in the Pacific Basin (Brillon 2016) include Japan in 2011 (magnitude 9.1), Alaska in 1964 (magnitude 9.2), the Aleutian Islands in 1957 (magnitude 9.1) and 1946 (magnitude 8.1), Kamchatka in 1952 (magnitude 9.1) and Cascadia in 1700 (magnitude 8.7-9.2).

Although earthquake-triggered tsunami deposits are described from the southwest British Columbia (e.g. Clague \& Bobrowsky 1994; Hutchinson et al. 1997; Hutchinson \& Clague 2017), knowledge gaps remain in understanding the frequency and magnitude of paleo-seismic events for much of coastal British Columbia. For Douglas Channel, modelling of the 1964 Alaska earthquake suggests an arrival time of four hours after the event, with wave heights not exceeding $1 \mathrm{~m}$ occurring over more than eight hours at Kitimat (Skvortsov \& Bornhold 2007; Bornhold \& Thomson 2012; Thomson et al. 2012). It is uncertain whether this modest response left a sedimentological record in terrestrial soils of Douglas Channel.

\section{$3 \quad$ Methods}

\subsection{Purpose of study}

In this paper, ground-based observations are used to benchmark interpretations of RADARSAT-2 imagery, and inform InSAR analyses of deep-seated bedrock fractures and other landslide activity near the coastal community of Hartley Bay, Douglas Channel.

\subsection{Terrain mapping and field descriptions}

Terrain and stability mapping followed British Columbia (British Columbia Ministry of Forests 1999) and GSC mapping standards (Deblonde et al. 2018). Terrain classifications were hutchbased on slope gradient, surficial materials, material texture, material thickness, slope morphology, moisture conditions, and ongoing geomorphic processes (Maynard et al. 2017; Figure 3). Shuttle radar topographic mapping (SRTM) data was downloaded from http://srtm.cigar-csi.org to generate a 3-arc-second resolution digital elevation model of the region. From this DEM, a slope map was generated using Global Mapper software (Blue Marble Geographics 2020) and draped over Douglas Channel CHS Chart 3977. This base map (see Figures 2, 4, and 5) distinguished slopes $<15^{\circ}$ (light grey polygons), between $16^{\circ}$ and $34^{\circ}$ (white areas), and $>35^{\circ}$ (dark grey polygons).

Ground-based observations of geology and geomorphology were made during: 1) Canadian Coast Guard Ship cruises to the Queen Charlotte Sound, Hecate Strait and Douglas Channel in 2013, 2014 and 2015; and 2) helicopter, truck and jet boat traverses in the Prince Rupert, Kitimat and Terrace areas between 2014 and 2016 (Lintern et al. 2016; Huntley et al. 2018). Field stations were located and measured with a handheld Garmin ${ }^{\mathrm{TM}}$ GPS unit and a Thommen ${ }^{\mathrm{TM}}$ altimeter, with accuracies of $+/-5 \mathrm{~m}$ elevation. The relative elevation of soil observation pits above high tide as defined by storm berm deposits was also recorded. 


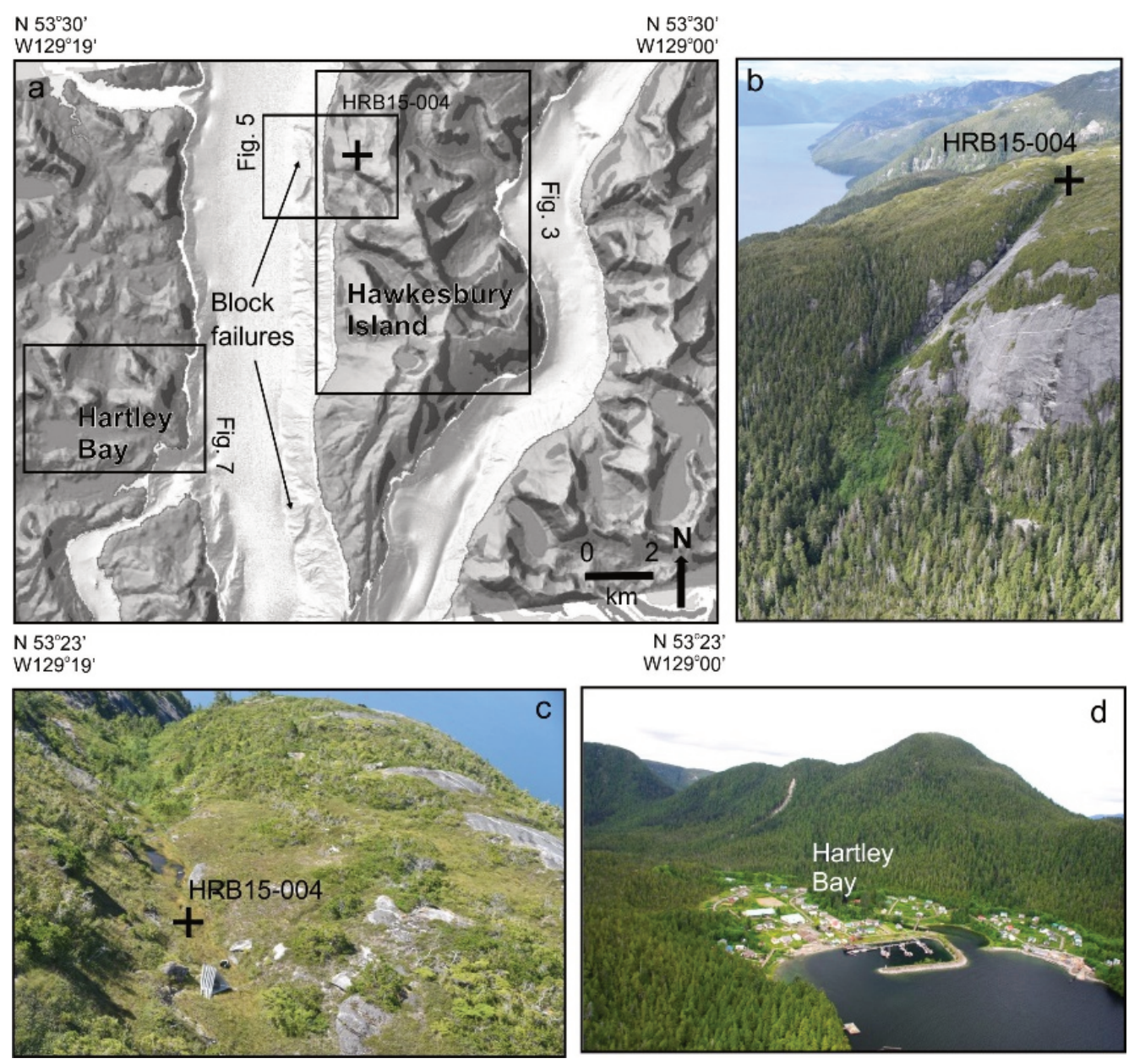

Figure 4 (a) South end of Hawkesbury Island showing location of ground observation point HRB15-004 in relation to relict submarine block failures, terrain slope classes (see Figure 2) derived from shuttle radar topographic mapping 3-arc-second DEM using Global Mapper ${ }^{\mathrm{TM}}$ software (version 10) merged with multi-beam sonar imagery modified from Shaw \& Lintern (2016); (b) Morphologically similar sackung-like bedrock fracture upslope of north submarine block failure - hanging wall to left, footwall to right; (c) Oblique view south of fracture with ephemeral ponds and channels along strike; (d) Oblique view northwest of Hartley Bay with debris flow in watershed.

New terrestrial sedimentary records of past geohazard events in coastal British Columbia were collected in the vicinity of the communities of Kitimat, Kitamaat and Hartley Bay (Figures 1(a) and (b); Huntley et al. 2018). Pedological descriptions followed the conventions of the Canadian system of classification (cf. Soil Classification Working Group 1998). Mineral soil horizons and parent surficial deposits were distinguished by erosion surfaces, fissility, consolidation, texture, clast lithologies and organic content. Organic soils (i.e. folisols and peats) were described by their degree of decomposition and field estimates of bulk density and porosity. Relative stratigraphic positions, surface expression and landform associations provided reference points for comparing soils and surficial units across the study area.

\subsection{InSAR methods}

Slope deformation on the western flank of Hawkesbury Island from 15 September 2016 and 14 July 2019 was monitored using a number of InSAR techniques (cf. Jónsson \& Ágústsson 2005; Clark et al. 2011; Dehls et al. 2014; Booth et al. 2015; Bardi et al. 2016; Serey et al 2019). Five trihedral aluminium corner reflectors were flown to the island by helicopter (Figure $5(\mathrm{a})$ ) and installed on bedrock blocks separated by a deep-seated fracture near the tree-line (Figures 5(b) and (c)). Two corner reflectors (GSC-1 and GSC-2) were positioned 
on stable bedrock east of the fractured block (Figure 4(b)). Once georeferenced with the handheld Garmin ${ }^{\mathrm{TM}}$ global positioning system (UTM zone 10, NAD83; $x, y+/-3 m ; z+/-5 m$ ), these permanent coherent artificial InSAR targets improved the precision and accuracy of subsequent image processing of RADARSAT-2 images acquired from the Canadian Space Agency (CSA) (Figure 6).
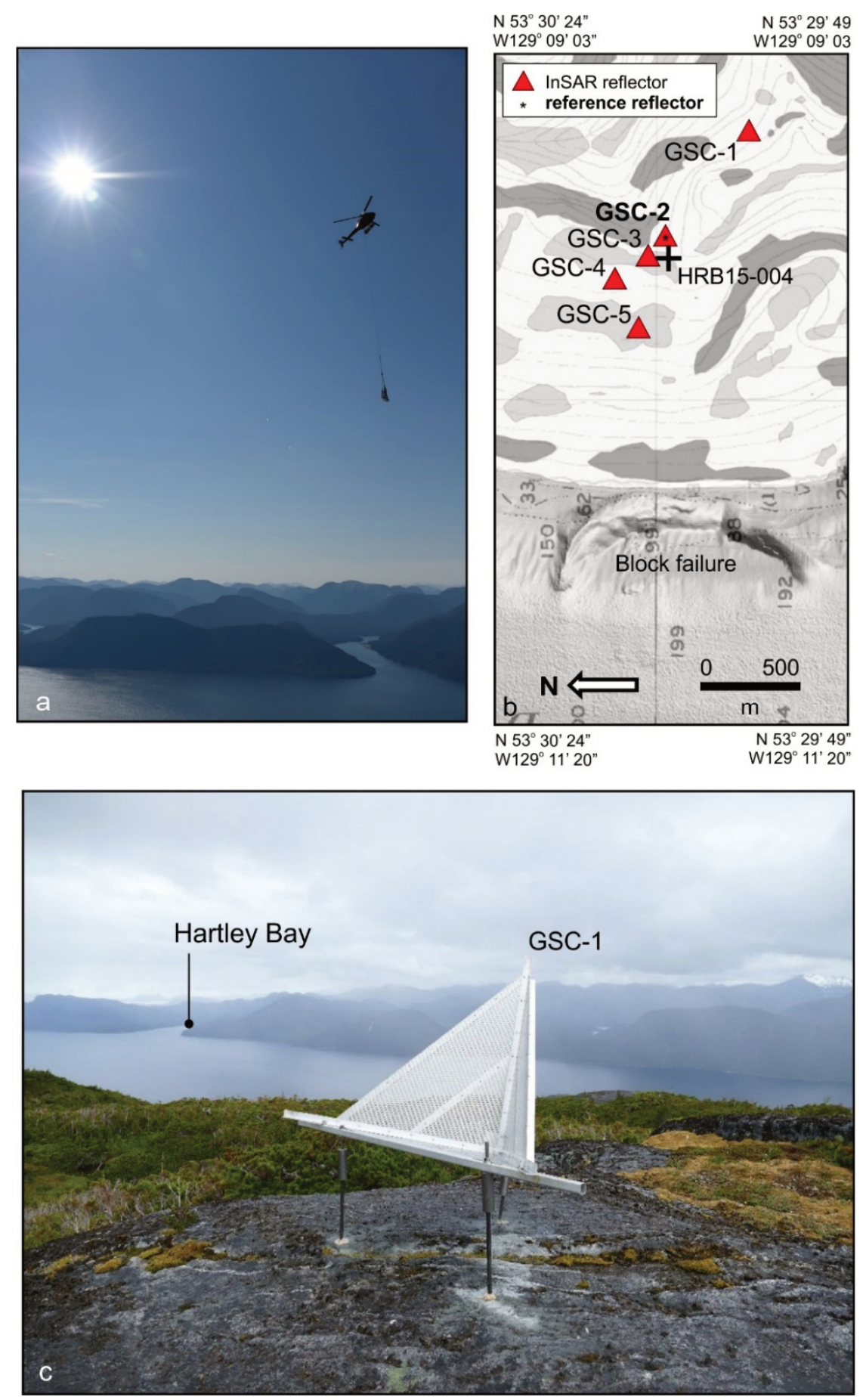

Figure 5 (a) Douglas Channel and the Kitimat Ranges, with InSAR corner reflectors being flown to Hawkesbury Island by an A-Star helicopter; (b) Locations of corner reflectors in relation to major deep-seated bedrock fractures and submarine block failure, terrain slope classes derived from shuttle radar topographic mapping 3-arc-second DEM using Global Mapper software (Blue Marble Geographics 2020), multi-beam sonar imagery modified from Shaw \& Lintern (2016), water depths in fathoms (see Figure 4 for location); (c) Trihedral corner reflector installed in tonalite bedrock, located in the alpine tundra of Hawkesbury Island 
Multi-temporal averaging of a stack of 32 SAR scenes was used to reduce speckle on the final image (Figure 6). GAMMA Software (Wegmüller et al. 2016) was used to create a single-look multi-temporal interferogram network stack consisting of 171 independent interferometric measurements at each corner reflector between 30 June 2017 and 14 July 2019. This highly redundant network was used to create a deformation time series for each corner reflector using a multi-baseline approach. The same software was also used to create an example interferogram map from a pair of RADARSAT-2 SAR images covering the period from 17 July 2018 to 20 June 2019 (Figure 7). Scenes were acquired with a right-looking line-of-sight geometry from descending orbital passes. The interferogram map was multilooked by a factor of four in both the range and azimuth direction, and was corrected for a mean phase bias (i.e. a first order atmospheric correction).

Submillimeter accuracy of corner reflector time series has been demonstrated experimentally (Ferretti et al. 2007). InSAR corner reflectors were identified from the stack of SAR imagery by examining the degree of phase stability over time for every resolution cell within the study area. By considering only targets with persistent scatterer characteristics, and correcting for phase change contributions caused by orbital position errors, topography and atmospheric effects, a time series of deformation for each target was recovered with measurement accuracies of several mm (cf. Henschel et al. 2015).

\section{$4 \quad$ Results}

\subsection{Air photo and ground-based observations}

\subsubsection{Hawkesbury Island}

Hawkesbury Island is a relict alpine glacial landscape dominated by cirque basins, horns, arêtes, truncated spurs, deeply incised U-shaped valleys, and hanging valleys draining into the Kitimat fjord (Figure 4(a)). Steep bedrock slopes $\left(>35^{\circ}\right)$ are prone to weathering and rockfall, and accumulate talus deposits at their base. Steep terrain, and dense forest cover limits access on Hawkesbury Island to the upper slopes of the fjord.

Deep-penetrating N-S oriented bedrock fractures, subparallel to slope, dip to the west into Douglas Channel (Figure 4(b)). Rock mass areas bounded by these fractures range from $1 \mathrm{~km}^{2}$ (south) to $2 \mathrm{~km}^{2}$ (north). Smaller fractures in the hanging walls dip steeply west, and terminate along the footwall plane of the major fractures. Joint sets dip out of the slope at less steep angles. The orientation of these penetrative fractures is consistent with the regional dextral shear stress regime (Rohr \& Tryon 2010; Brillon 2016).

On the ground, tonalite and gneissic outcrops are crosscut by a reticulate network of centimetre-thick quartz-rich veins, and metre-scale basic dykes and sills (Nelson et al. 2012). Bedrock is glacially streamlined, indicating southward flow of ice along the Douglas Channel. Colluvial deposits are dominant on the slopes; glacial deposits (e.g. till diamicton) are generally absent; and krummholz forest cover develops over an organic veneer ( $<50 \mathrm{~cm}$ thick) of Folisol (Figure 3). Shallow, beaded ponds and ephemeral streams form along the fracture traces during the summer months (Figure 4(c)). Closed depressions, infilled with mineral-rich peat, capture snow melt, surface runoff and spring flow, and drain partly through the underlying fracture system.

\subsection{SAR images and InSAR analysis}

\subsubsection{Hawkesbury Island}

The orthorectified, averaged resampled multilook intensity (RMLI) SAR image (Figure 6) clearly captures bedrock blocks with deep-penetrating N-S oriented fractures dipping west into Douglas Channel. Smaller, near vertical NE-SW and NW-SE fracture sets are also visible, terminating against, and bounding the $\mathrm{N}-\mathrm{S}$ lineaments. 


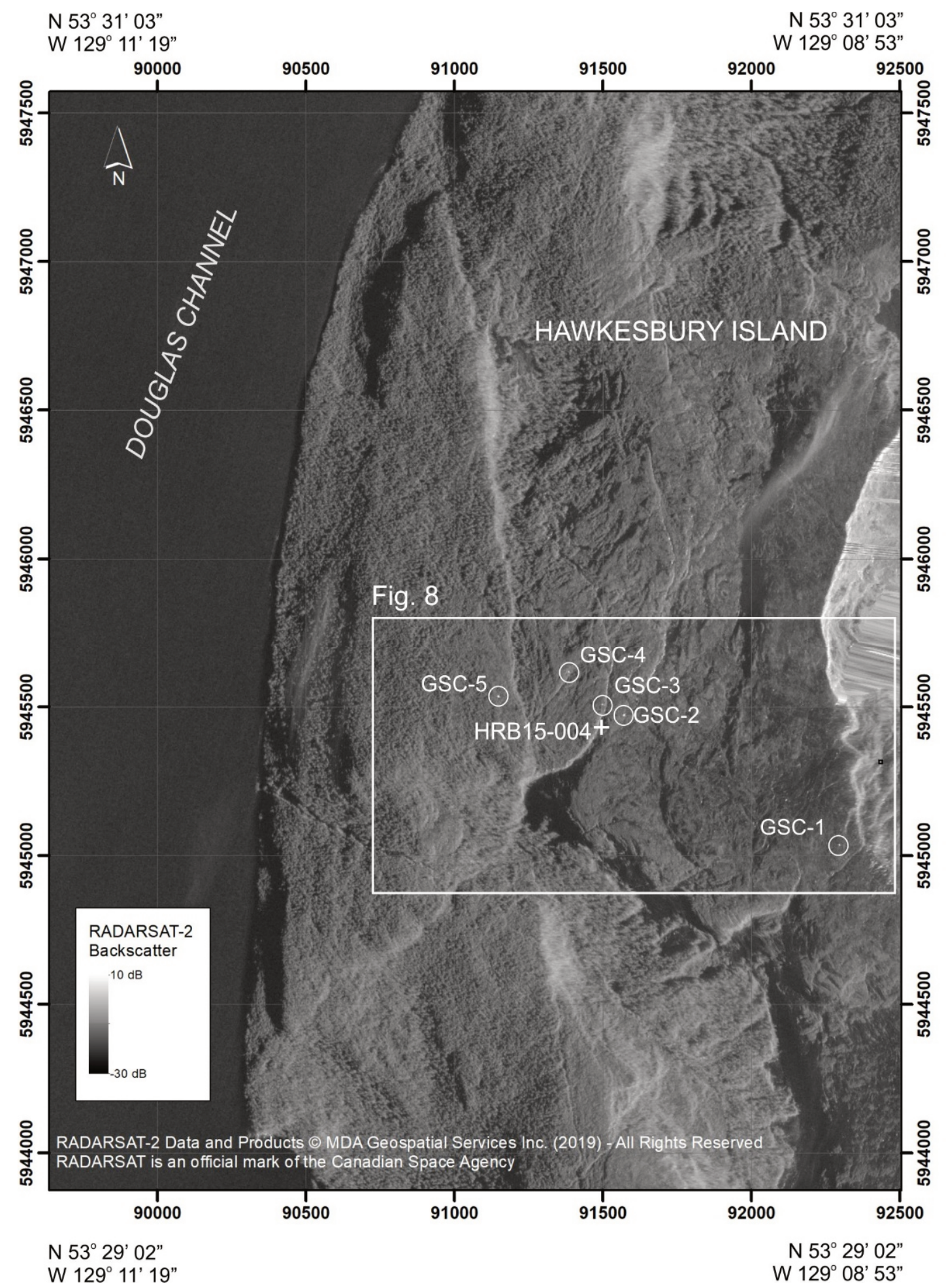

Figure 6 Orthorectified RADARSAT-2 averaged resampled multilook intensity (backscatter) SAR image of Hawkesbury Island, Douglas Channel, and location of trihedral corner reflectors; GSC-2 is used as the reference corner reflector for analyses (inset box shows location of Figure 8) 


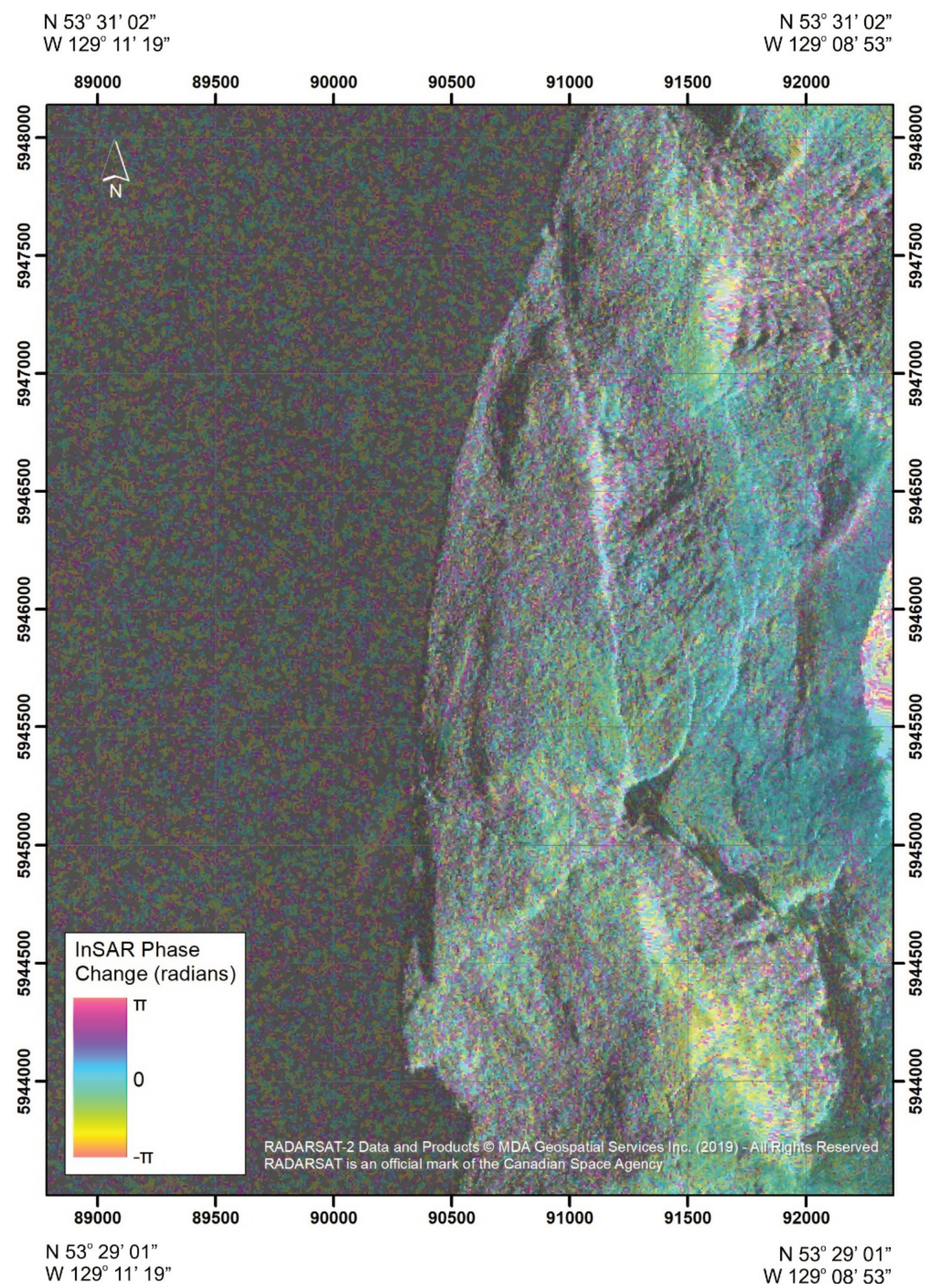

Figure 7 Interferogram map of Hawkesbury Island from 17 July 2018 to 20 June 2019. Average line-of-sight velocity will be calculated using RADARSAT-2 Ultrafine data in a future study

InSAR phase changes between 17 July 2018 and 20 June 2019 are shown in Figure 7. There is some variability in phase response, but no strong phase anomalies. This processed image shows no large-scale movement of the blocks during this time period, at least where the corner reflectors are located (Figure 6). The mild transition from blue to yellow over the main block of interest indicates displacement of $<5 \mathrm{~mm} /$ year. This is 
below the atmospheric uncertainty for the single interferogram, and does not definitively rule out very slow creep over the one year observation period. Further orbit baseline refinement, atmospheric phase correction, and time series measurements are required for a quantitative analysis (outside the scope of this work).

All five corner reflectors installed on 20 June 2017 were located in the RADARSAT- 2 imagery based on their known install locations and their backscattering characteristics. Backscatter amplitude characteristics were analysed through the image stack to identify and remove any unreliable corner reflector measurements from processing. Several dates where the backscatter amplitude of corner reflectors was low for a period of months were identified from the time series profiles (Table 1, Figure 8). As these periods occurred over the winter months and repeated annually, it is assumed that snow cover obscured the corner reflector backscatter during these winter periods. InSAR phase measurements from interferograms formed with SAR images acquired on these dates were discarded as they were deemed to be unreliable.

\section{Table 1 Low corner reflector backscatter dates omitted from processing}

\begin{tabular}{l}
\hline Omitted RADARSAT-2 image date \\
\hline 8 January 2018 \\
1 February 2018 \\
25 February 2018 \\
21 March 2018 \\
14 April 2018 \\
16 March 2019 \\
\hline
\end{tabular}

The backscatter time series profile for proposed stable reference reflector GSC-1 (Figure 8, top left) increased to the expected level in the acquisition immediately following installation. However, by 14 April 2019, backscatter decreased to a level similar to pre-installation, a level more consistent with the surrounding undisturbed ground surface. It is possible that the corner reflector was damaged by winter weather, wildlife, or some other forces. The specific reason remains unknown until a site visit can be arranged. It is clear from the backscatter profile that the corner reflector is unable to provide reliable measurements, and is no longer suitable as a stable phase reference. Corner reflector GSC-2 was substituted as the stable reference reflector in place of GSC-1 to generate the deformation time series (Figures 5(b), 6, and 8).

\subsubsection{Hartley Bay}

The channelised debris flow northwest of Hartley Bay (Figure 4(d)) is visible in the SAR image for 10 September 2017 (Figure 9(b)). By 8 January 2018, two additional elongated slope failures are distinguishable on the SAR image on southwest-facing slopes with mature forest cover (Figure 9(c)). Debris flow 1, $3 \mathrm{~km}$ west-northwest of Hartley Bay, is $800 \mathrm{~m}$ long, and terminates in a gulley $200 \mathrm{~m}$ upstream of Lower Lake; the flow scar is between $50 \mathrm{~m}$ and $100 \mathrm{~m}$ wide. Debris flow 2 lies in a separate watershed $2.15 \mathrm{~km}$ north of Hartley Bay (Figure 9(c)). This smaller feature is $300 \mathrm{~m}$ long. The upper $200 \mathrm{~m}$ of the gulley scoured a channel approximately $50 \mathrm{~m}$ wide; the lower $100 \mathrm{~m}$ forms a bifurcated run-out zone $100 \mathrm{~m}$ wide, terminating $100 \mathrm{~m}$ from the confluence with a larger stream.

Also noticeable on the two SAR images is a change in elevation of lake level from September 2017 to January 2018 (Figures 9(b) and 9(c). This is most likely attributed to the addition of runoff during intense fall and winter storms. Weather data (including rainfall and snowmelt) from Kitimat, $80 \mathrm{~km}$ north, indicate $>1.2 \mathrm{~m}$ of total precipitation between fall and winter in the Douglas Channel watershed (Table 2). 

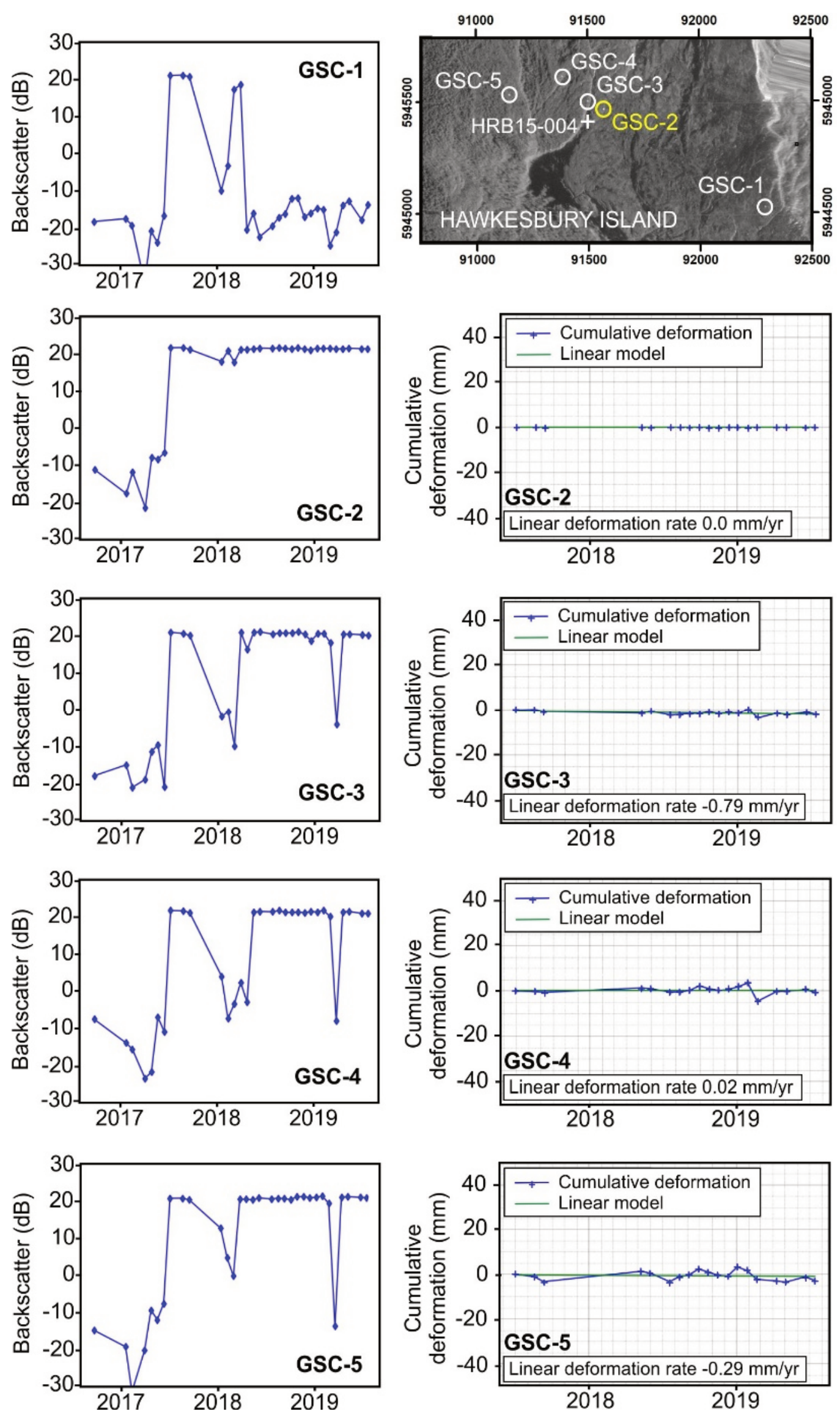

Figure 8 Backscatter plots (left) and linear line-of-sight displacement plots (right) from June 2017 to July 2019 for Hawkesbury Island 
Table 2 Total precipitation values $(\mathrm{mm})$ for Kitimat (Climate ID: 1064321) from September 2017 to January 2018 (source of date: climate.weather.gc.ca)

\begin{tabular}{ll}
\hline Month & $\begin{array}{l}\text { Total precipitation }(\mathrm{mm}) \text { - } \\
\text { rainfall + snowmelt }\end{array}$ \\
\hline September 2017 & 221 \\
October 2017 & 478 \\
November 2017 & 308 \\
December 2017 & 89 \\
Total antecedent & 1096 \\
January 2018 & 202 \\
Total & $\mathbf{1 2 9 8}$ \\
\hline
\end{tabular}

\section{$5 \quad$ Discussion and summary}

Communities, economic infrastructure, the environment, and natural resources along the fjord coastlines of Canada, Alaska, Norway, Iceland, Greenland, Chile, and New Zealand are vulnerable to tsunamis generated by earthquakes, volcanic activity, or during rapid ingress of large volumes of rock and debris into narrow channels, inlets and embayments (e.g. Blikra et al. 2005; Suleimani et al. 2009; Harbitz et al. 2014; Lastras et al. 2016; Overeem et al. 2016; Gylfadóttir et al. 2017; Gauthier et al. 2018). In these regions, pre-existing valleys are eroded during glaciation to produce characteristic U-shaped fjords with steep side flanks, overdeepened and flattened floors, and submerged moraine sills. Glacial loading produces stress fractures in fjord side walls, further preparing slopes for failure during ice retreat. Similar to glacial end times, modern climate change is leading to rapid ice-melt from alpine and arctic coastal regions around the world. This loss of glacial ice buttressing steep slopes leads to an expansion of fractures as stress is released. Paraglacial debuttressing, combined with glacio-isostatic rebound, neo-tectonic faulting, and the thawing of permafrost, increases the likelihood of rockfalls, deep-seated gravitational slope deformation, and catastrophic rock avalanches (Jaboyedoff et al. 2011; Mercier et al. 2012; Higman et al. 2018).

In tectonically active regions, seismic events can directly generate tsunamis during crustal displacement, but also trigger large volume rock slides, flows, avalanches, and falls that also generate damaging and fatal displacement waves. Displacement waves triggered by landslides can have much shorter periodicity and higher run-ups than seismogenic tsunamis. Seismic shaking also triggers smaller, shallow soil and soil-rock slides, and debris flows that also impact communities, infrastructure, the environment, and natural resources (Power et al. 2003; Suleimani et al. 2009; Uslu et al. 2009; Sepúlveda et al. 2010; Higman et al. 2018).

\subsection{Observations relevant to future risk assessments}

For the communities, economic infrastructure, and natural resources of Douglas Channel, geohazard risks are conventionally defined in terms of injuries and deaths, property and economic losses, and environmental damage as a consequence of recurring geomorphic processes (cf. Fell 1994; Hermanns et al. 2016).

The results of the 2017-2019 InSAR analysis suggests that, at least on short time-scales (<2 years), the western flank of Hawkesbury Island is not rapidly deforming. As such, the deep-seated, sackung-like bedrock fractures are likely relict (paraglacial), inactive features $>10,000$ years old, related to stress release and debuttressing of the fjord side walls, glacio-isostatic rebound, neo-tectonic faulting, and permafrost loss during deglaciation. Time series measurements from GSC-2, GSC-3, GSC-4, and GSC-5 all show less than $3 \mathrm{~mm}$ of cumulative deformation throughout the analysis period and linear deformation rates of less than $1 \mathrm{~mm} /$ year. These values fall near the magnitude of demonstrated uncertainty for InSAR (Ferretti et al. 2007; Henschel et al. 2015). This indicates either that there is minimal deformation occurring at the corner reflector 
locations during this analysis period, or that the deformation zone extends beyond the four corner reflectors used in the analysis, and they are all moving in unison. Visual inspection of longer period coherent differential interferograms do not display any obvious strong deformation signals.

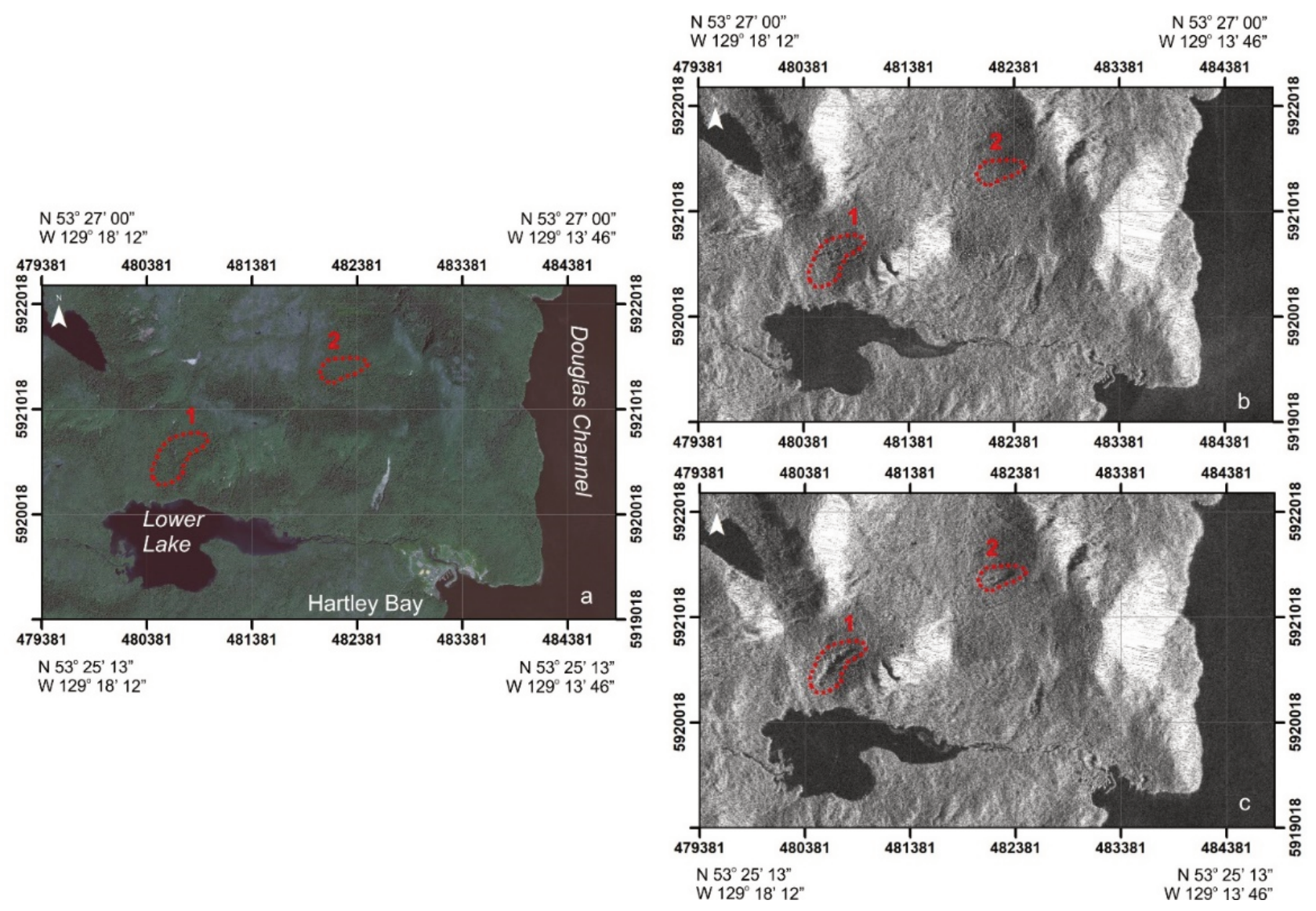

Figure 9 (a) Channelised debris flows on steep mountain slopes in the vicinity of Hartley Bay, with location of new debris flows ( 1 and 2 ) outlined in red, optical image of Hartley Bay prior to September 2017; (b) SAR image for 10 September 2017; (c) SAR image for 8 January 2018 with new debris flows visible; RADARSAT-2 data and products (C) Geospatial Services Inc. (2019); RADARSAT-2 is an official mark of the Canadian Space Agency

This finding has implications for future landslide and tsunami risk assessments in Douglas Channel. Unless re-activated by local earthquakes of sufficient magnitude (an unlikely scenario based on recent GSC seismic monitoring in the region), the stable sackung-like features on the western flank of Hawkesbury Island are not a geological hazard to fjord-bound communities (e.g. Hartley Bay, Kitamaat, Kitimat), coastal infrastructure (e.g. LNG and DILBIT storage, deep-water port facilities, government docks), and natural resource activities (e.g. fishing, logging, tourism). At present, paraglacial landslides are stabilised features and represent the lowest likelihood for reactivation and triggering of tsunamis (Table 3). Coastal communities and infrastructure are most likely to experience damage and loss of life through displacement waves generated by large volume submarine slumps and terrestrial debris flows (Table 3). In the mid-1970s, low tides, groundwater conditions, flooding, and anthropogenic activities combined to trigger slumps from the Kitimat River delta that caused significant damage to coastal infrastructure in Kitamaat and Kitimat (Table 3). Considerable development has occurred in Douglas Channel since the last century and is now vulnerable to damage from submarine slumps and resultant tsunamis. The distribution of marine inundation deposits in Douglas Channel suggest that Pacific-sourced earthquake-triggered tsunamis and storm surges expend much of their energy in the outer channels, reefs, coves and peninsulas, and rarely reach far up the mainland fjords (Table 3; Huntley et al. 2018). 
Table 3 Geomorphological processes and landforms in Douglas Channel, their potential to trigger tsunamis, and their appearance on RADARSAT-2 images; see Figure 2 for location of major features

\begin{tabular}{|c|c|c|}
\hline $\begin{array}{l}\text { Geomorphic process } \\
\text { Event magnitude/occurrence frequency }\end{array}$ & $\begin{array}{l}\text { Tsunami } \\
\text { potential }\end{array}$ & Appearance on RADARSAT-2 images \\
\hline \multicolumn{3}{|c|}{$\begin{array}{l}\text { Paraglacial landslides } \\
\text { areal extent }=\mathrm{km}^{2} \text {, volume }=\mathrm{km}^{3} ; \text { recurrence frequency }=100 \mathrm{~s}-1000 \text { s of years }\end{array}$} \\
\hline $\begin{array}{l}\text { Complex submarine failure } \\
\text { large volume/low frequency }\end{array}$ & Yes & Submerged feature; not visible \\
\hline $\begin{array}{l}\text { Bedrock avalanche } \\
\text { large volume/low frequency }\end{array}$ & Yes & Changes in land surface; high reflectance \\
\hline $\begin{array}{l}\text { Bedrock creep } \\
\text { large area/high magnitude }\end{array}$ & No & Interferometric changes in land surface \\
\hline $\begin{array}{l}\text { Sackung } \\
\text { large volume/low magnitude }\end{array}$ & No & Interferometric changes in land surface \\
\hline \multicolumn{3}{|c|}{$\begin{array}{l}\text { Postglacial landslides } \\
\text { areal extent }=m-k m^{2} \text {, volume }=m^{3}-k m^{3} / \text { recurrence frequency }=1 \mathrm{~s}-10 \text { s of years }\end{array}$} \\
\hline $\begin{array}{l}\text { Rockfall } \\
\text { small volume/high frequency }\end{array}$ & No & Changes in land surface; high reflectance \\
\hline $\begin{array}{l}\text { Debris flow/slide } \\
\text { small volume/high frequency }\end{array}$ & No & Changes in land surface; high reflectance \\
\hline $\begin{array}{l}\text { Submarine slump } \\
\text { large volume/moderate frequency }\end{array}$ & Yes & Submerged feature; not visible \\
\hline \multicolumn{3}{|c|}{$\begin{array}{l}\text { Other triggering processes } \\
\text { discharge }=\mathrm{m}^{3} \mathrm{~s}^{-1} ; \text { areal extent }=\mathrm{km}^{2}, \text { volume }=\mathrm{km}^{3} ; \text { magnitude/recurrence frequency }=10 \mathrm{~s}-100 \text { s years }\end{array}$} \\
\hline $\begin{array}{l}\text { Flooding } \\
\text { high discharge/moderate frequency }\end{array}$ & Yes & Changes in water surface, low reflectance \\
\hline $\begin{array}{l}\text { Storm surge } \\
\text { high tide/moderate frequency }\end{array}$ & Yes & Changes in water surface; low reflectance \\
\hline $\begin{array}{l}\text { Tides } \\
\text { high tidal range/moderate frequency }\end{array}$ & Yes & Changes in water surface; low reflectance \\
\hline $\begin{array}{l}\text { Local earthquake } \\
\text { low magnitude/moderate frequency }\end{array}$ & No & Interferometric changes in land surface \\
\hline $\begin{array}{l}\text { Plate boundary earthquake } \\
\text { high magnitude/low frequency }\end{array}$ & Yes & Interferometric changes in land surface \\
\hline $\begin{array}{l}\text { Anthropogenic activities } \\
\text { increasing land use/high frequency }\end{array}$ & Yes & Changes in land surface; high reflectance \\
\hline
\end{tabular}

A terrain stability assessment for the southern portion of the Douglas Channel and Hartley Bay shows some colluvial terrain located close to the shoreline assessed with a moderate and high likelihood of landslides (levels IV and V, Figure 3; Blais-Stevens et al. 2016; Maynard et al. 2017). Frequent, smaller volume events (e.g. rockfalls and debris flows) do not generate tsunamis of any consequence. However, evidence of marine inundation in forest soils near Kitimat indicates that tsunamis are locally triggered by infrequent large landslides and marine slumps, or distant earthquakes (Huntley et al. 2018). 
Debris flows near Hartley Bay occurred between middle September 2017 and early January 2018 (Figures 9(b) and 9(c), suggesting both were triggered during fall or winter storm events. Facing southwest, the steep, forested slopes are favourably positioned for receiving large amounts of rain and snow during north-easterly tracking storms. Climate data for Kitimat, $80 \mathrm{~km}$ north (the closest operational weather station), indicate significant antecedent rainfall and snowfall (>1 m) prior to detection of the debris flows (Table 2). The extent to which the debris flows detected in the January 2018 SAR image of the Hartley Bay area impacted local watersheds has yet to be determined by ground observations and public consultation. The southernmost debris flow likely introduced some sediment into Lower Lake, potentially compromising the potable water supply for the village of Hartley Bay. Larger volume debris flows or slides entering Lower Lake could generate tsunamis that will pose a flooding hazard to the community. Changes in lake elevation in response to rain and snow events between September 2017 and January 2018 are clearly shown in Figures 9(b) and 9(c). This study shows that SAR image analysis is an effective tool for identifying debris flows, and limits of lake flooding.

Future extreme weather events will likely result in an increase of magnitude and frequency of storm surges and floods into Douglas Channel. In turn, such conditions are expected to trigger slope erosion, local large volume landslides, and fast-moving tsunami events (Table 3). These geohazards are potential threats to the safety and security of local communities (e.g. Hartley Bay, Kitimat and Kitamaat), existing and planned tide water infrastructure (e.g. recreational docks and deep-water port facilities), in addition to sensitive ecosystems, and natural resources (e.g. coastal wetlands, marine mammals, salmon populations, and potable water supplies).

\subsection{Summary}

InSAR phase changes and backscatter time series show there has been no large-scale deformation of the western flank of Hawkesbury Island between 17 July 2018 and 20 June 2019 (Figure 7), particularly where the corner reflectors are located (Figure 8). The provisional InSAR analysis presented here supports the contention that the deep-seated, sackung-like bedrock fractures are inactive (i.e. currently stable) paraglacial features that likely formed by stress release during debuttressing of side walls, glacio-isostatic rebound, neo-tectonic faulting, and permafrost loss during deglaciation.

This initial assessment will be tested in the coming years with further InSAR analysis and monitoring using other satellite platforms (e.g. RADARSAT Constellation and SENTINEL-1). Analysis of longer InSAR time series may reveal extremely slow displacement of slopes and rockfall activity in the vicinity of critical infrastructure and communities in Douglas Channel. Unstable slopes identified through terrain mapping and InSAR techniques could be verified and further monitored with differential global positioning systems and photogrammetry using unmanned aerial vehicles. Trenching and coring of peat deposits would also provide insight into drainage and movement history across the deep-seated fractures on Hawkesbury Island. Geoscience outreach and public engagement will help inform those communities.

SAR imagery has also effectively captured the occurrence of moderately large volume debris flows and flooding triggered by seasonal changes in precipitation in the vicinity of Hartley Bay (Figure 9). Such landslides and floods have the potential to adversely impact the community, sensitive ecosystems, and natural resources (e.g. salmon populations and potable water supplies). 


\section{Acknowledgement}

The authors would like to thank GSC research scientists and technicians for field support; Natural Resources Canada management for project support; officers and crew of Canadian Coast Guard Ships John Tully and Vector for logistical support; and the First Nations communities of Kitamaat and Hartley Bay for site access. The services of White River Helicopters and Kermodei Adventures in Terrace were also appreciated. The manuscript greatly benefitted from critical reviews by Andrée Blais-Stevens (GSC) and by an Anonymous Reader.

\section{References}

Ambrosi, C \& Crosta, G 2006, 'Large sackung along major tectonic features in the Central Italian Alps', Engineering Geology, vol. 83, pp. 183-200.

Bardi, F, Raspini, F, Ciampalini, A, Kristensen, L, Rouyet, L, Lauknes, T, Frauenfelder, R \& Casagli, N 2016, 'Space-borne and groundbased InSAR data integration: The Åknes test site', Remote Sensing, vol. 8, pp. 237-261, https://doi.org/10.3390/rs8030237

Barrie, J, Hetherington, R \& Macleod, R 2014, 'Chapter 22 Pacific margin, Canada shelf physiography: a complex history of glaciation, tectonism, oceanography and sea-level change', Geological Society, vol. 41, pp. 305-313, https://doi.org/10.1144/M41.22

Blais-Stevens, A, Maynard, D, Weiland, I, Geertsema, M \& Behnia, P 2016, 'Surficial geology and landslide inventory in Douglas Channel fjord, northwest British Columbia', GeoVancouver, Canadian Geotechnical Society, Toronto.

Blikra, L, Longva, O, Harbitz, C, Glimsdal, D \& Løvholt, F 2005, 'Quantification of rock-avalanche and tsunami hazard in Storfjorden, western Norway', in K Senneset, K Flaate \& JO Larsen (eds), Landslides and Avalanches, Taylor \& Francis Group, London, pp. 57-63.

Blue Marble Geographics 2020, Global Mapper, version 10, computer software, https://www.bluemarblegeo.com

Booth, A, Dehls, J, Eiken, T, Fischer, L, Hermanns, R \& Oppikofer, T 2015, 'Integrating diverse geologic and geodetic observations to determine failure mechanisms and deformation rates across a large bedrock landslide complex: the Osmundneset landslide, Sogn og Fjordane, Norway', Landslides, vol. 12, pp. 745-756.

Bornhold, B 1983, Sedimentation in Douglas Channel and Kitimat Arm, in R Macdonald (ed.), Proceedings of a Workshop on the Kitimat Marine Environment, Canadian Technical Report of Hydrography and Ocean Sciences, Sidney, vol. 21, pp. 71-87.

Bornhold, B \& Thompson, R 2012, 'Tsunami hazard assessment related to slope failures in coastal waters', in J Clague \& D Stead (eds), Landslides - Types, Mechanisms and Modelling, Cambridge University Press, Cambridge.

Brillon, C 2016, Baseline assessment of seismic hazard in British Columbia's north coast, Geological Survey of Canada, Open file 7994, 36 pageshttps://doi.org/10.4095/297566

British Columbia Ministry of Forests 1999, Mapping and assessing terrain stability guidebook, 2nd edn, Forest Practices Code of British Columbia, Victoria.

Clague, J 1984, 'Quaternary geology and geomorphology, Smithers-Terrace-Prince Rupert area, British Columbia', Geological Survey of Canada, https://doi.org/10.4095/119547

Clague, J 1985, 'Deglaciation of the Prince Rupert-Kitimat area, British Columbia', Canadian Journal of Earth Sciences, vol. 22, pp. 256-265.

Clague, J \& Bobrowsky, P 1994, 'Evidence for a large earthquake and tsunami 100-400 years ago on western Vancouver Island, British Columbia', Quaternary Research, vol. 41, pp. 176-184.

Clark, K, Johnson, P, Turnbull, I \& Litchfield, N 2011, 'The 2009 Mw 7.8 earthquake on the Puysegur subduction zone produced minimal geological effects around Dusky Sound, New Zealand', New Zealand Journal of Geology and Geophysics, vol. 54, pp. 237-247, https://doi.org/10.1080/00288306.2010.543690

Conway, K, Barrie, J \& Thomson, R 2012, 'Submarine slope failures and tsunami hazard in coastal British Columbia: Douglas Channel and Kitimat Arm', Geological Survey of Canada, Natural Resources Canada, https://doi.org/10.4095/291732

Conway, K \& Barrie, J 2015, 'Large submarine slope failures and associated Quaternary faults in Douglas Channel, British Columbia', Geological Survey of Canada, Natural Resources, Canada https://doi.org/10.4095/297316

Conway, K \& Barrie, J 2018, 'Large bedrock slope failures in a British Columbia, Canada fjord: first documented submarine sackungen', Geo-Marine Letters, vol. 38, pp. 195-209, https://doi.org/10.1007/s00367-018-0533-y

Deblonde, C, Cocking, R, Kerr, D, Campbell, J, Eagles, S, Everett, D...\& Weatherston, A 2018, 'Surficial Data Model: the science language of the integrated Geological Survey of Canada data model for surficial geology maps', Geological Survey of Canada, Natural Resources Canada, https://doi.org/10.4095/308178

Dehls, J, Lauknes, R, Hermanns, R, Bunkholt, H, Grydeland, T, Larsen, Y...\& Eiken, T 2014, 'Use of satellite and ground based InSAR in hazard classification of unstable rock slopes', Landslide Science for a Safer Geoenvironment, pp. 389-392, https://doi.org/ 10.1007/978-3-319-05050-8_60

Fell, R 1994, 'Landslide risk assessment and acceptable risk', Canadian Geotechnical Journal, vol. 31, pp. 261-272.

Ferretti, A, Savio, G, Barzaghi, R, Borghi, A, Musazzi, S, Novali, F...\& Rocca, F 2007, 'Submillimeter Accuracy of InSAR Time Series: Experimental Validation', IEEE Transactions on Geoscience and Remote Sensing, vol. 45, pp. 1142-1148.

Gauthier, D, Anderson, S, Hermann M, Fritz, H \& Giachetti, T 2018, 'Karrat Fjord (Greenland) tsunamigenic landslide of 17 June 2017 : initial 3D observations', Landslides, vol. 15, pp. 327-332. 
Golder Associates 1975, Report to British Columbia Water Resources Service on investigation of seawave at Kitimat, Golder Associates Inc., Vancouver.

Gylfadóttir, S, Kim, J, Helgason, J, Brynjólfsson, S, Höskuldsson, A, Jóhannesson, T...\& Løvholt, F 2017, 'The 2014 Lake Askja rockslideinduced tsunami: Optimization of numerical tsunami model using observed data', Journal of Geophysical Research: Oceans, vol. 122, pp. 4110-4122, https://doi.org/10.1002/2016JC012496

Harbitz, C, Glimsdal, S, Løvholt, F, Kveldsvik, V, Pedersen, G \& Jensen, A 2014, 'Rockslide tsunamis in complex fjords: From an unstable rock slope at Åkerneset to tsunami risk in western Norway', Coastal Engineering, vol. 88, pp. 101-122.

Henschel, M, Dudley, J, Lehrbass, B, Sato, S \& Stöckel, B-M 2015, 'Monitoring slope movement from space with Robust Accuracy Assessment', Proceedings of the 2015 International Symposium on Slope Stability in Open Pit Mining and Civil Engineering, The Southern African Institute of Mining and Metallurgy, Johannesburg, pp. 151-159.

Hermanns, R, Oppikofer, T, Böhme, M, Dehls, J, Yugsi Molina, F \& Penna, I 2016, 'Rock slope instabilities in Norway: first systematic hazard and risk classification of 22 unstable rock slopes from northern, western and southern Norway'. Landslides and Engineered Slopes. Experience, Theory and Practice, pp. 1107-1114.

Higman, B, Shugar, D, Stark, C, Ekström, G, Koppes, M, Lynett...\& Venditti, J 2018, 'The 2015 landslide and tsunami in Taan Fiord, Alaska', Scientific Reports, vol. 8, no. 12993, https://doi.org/10.1038/s41598-018-30475-w

Huntley, D, Bobrowsky, P, Goff, J, Chague-Goff, C, Stead, D., Donati, D \& Mariampillai, D 2018, 'Extending the terrestrial depositional record of marine geohazards in coastal northwest British Columbia', in D Lintern \& D. Mosher (eds), Subaqueous Mass Movements and Their Consequences: Assessing Geohazards, Environmental Implications and Economic Significance of Subaqueous Landslides, Geological Society of London Special Publication 17, London.

Hutchinson, I, Clague, J \& Mathewes, R 1997, 'Reconstructing the tsunami record on an emerging coast: a case study of Kanim Lake, Vancouver Island, British Columbia', Canada, Journal of Coastal Research, vol. 13, pp. 545-553.

Hutchinson, I \& Clague, J 2017, 'Were they all giants? Perspectives on late Holocene plate-boundary earthquakes at the northern end of the Cascadia subduction zone', Quaternary Science Reviews, vol. 169, https://doi.org/10.1016/j.quascirev.2017.05.015

Jaboyedoff, M, Oppikofer, T, Derron, M, Blikra, L, Böhme M \& Saintot A 2011, 'Complex landslide behaviour and structural control: a three-dimensional conceptual model of Åknes rockslide, Norway', Geological Society of London Special Publication, London, no. 351, pp. 147-161, https://doi.org/10.1144/SP351.8

Jónsson, S \& Ágústsson, K 2005, 'Landslides in Iceland studies using SAR interferometry', Proceedings of the 2004 Envisat and ERS Symposium, ESA SP-572, Salzburg, Austria, 5 p.

Journault, J, Macciotta, R, Hendry, M, Charbonneau, F, Huntley, D \& Bobrowsky, P 2018, 'Measuring displacements of the Thompson River valley landslides, south of Ashcroft, B.C., Canada, using satellite InSAR', Landslides, vol. 15, pp. 621-636, https://doi.org/10.1007/s10346-017-0900-1

Lastras, G, Amblas, D, Canals, M \& DETSUFA Shipboard Party 2016, 'Fjord-flank collapse and associated deformation in Aysén Fjord, Chile', Geological Society of London, London, no. 46, pp. 107-108, https://doi.org/10.1144/M46.15

Lintern, D, Stacey, C, Shaw, J, Koshure, N, Barrie, J, Bobrowsky...\& Robertson A 2016, 'CCGS Tully 2014007PGC Cruise report', Geological Survey of Canada, Natural Resources Canada, https://doi.org/10.4095/296566

Lintern, G, Blais-Stevens, A, Bobrowsky, P, Conway, K, Huntley, D, Mackillop...\& Hill, P 2018, 'Providing multidisciplinary science advice for coastal planning in Kitimat Arm, British Columbia', in D Lintern \& D Mosher (eds), Subaqueous Mass Movements and Their Consequences: Assessing Geohazards, Environmental Implications and Economic Significance of Subaqueous Landslides, Geological Society of London Special Publication 17, London.

Luternauer, J \& Swan, D 1978, 'Kitimat submarine slump deposit(s): a preliminary report', Geological Survey of Canada, Current Research, pp. 327-350.

Maynard, D, Weiland, I, Blais-Stevens, A \& Geertsema, M 2017, 'Surficial geology, Hartley Bay, Douglas Channel area, British Columbia, parts of NTS 103-H/6 and 11', Geological Survey of Canada, Natural Resources Canada, https://doi.org/10.4095/299824

Mercier, D, Cossart, E, Decaulne, A, Feuillet, T, Páll Jónsson, H \& Sæmundsson, p 2012, 'The Höfðahólar rock avalanche (sturzström): Chronological constraint of paraglacial landsliding on an Icelandic hillslope', The Holocene, vol. 23, issue 3, pp. 432-446, https://doi.org/10.1177/0959683612463104

Murty, T 1979, 'Submarine slide-generated water waves in Kitimat, British Columbia', Journal of Geophysical Research, vol. 84, pp. 7777-7779.

Nelson, J, Diakow, L, Mahoney, B, van Staal, C, Pecha, M, Angen, J...\& Lau, T 2012, 'North Coast Project: tectonics and metallogeny of the Alexander Terrane, and Cretaceous sinistral shearing of the Western Coast Belt', Geological Fieldwork 2011, British Columbia Ministry of Energy and Mines, pp. 157-180.

Overeem, I, Lintern, D \& Hill, P 2016, 'A sensitivity analysis of triggers and mechanisms of mass movements in fjords', American Geophysical Union, Washington.

Power, W, Downes, G, Mcsaveney, M, Beavan, J \& Hancox, G 2003, 'The Fiordland Earthquake and Tsunami, New Zealand', Tsunamis, Advances in Natural and Technological Hazards Research Series, vol. 23, pp. 31-42.

Prior, D, Bornhold, B, Coleman, J \& Bryant, W 1982, 'Morphology of a submarine slide, Kitimat Arm, British Columbia', Geology, vol. 10, pp. 588-592.

Rohr, K \& Tryon, A 2010, 'Pacific-North America plate boundary reorganization in response to a change in relative plate motion; offshore Canada', Geochemistry Geophysics Geosystems, vol. 11, issue 6, https://doi.org/10.1029/2009GC003019

Scepter, D \& Schwab, J 1995, 'Rainstorm and flood damage: northwest British Columbia 1891-1991', Land Management Handbook 31, 203 pages, https://www.for.gov.bc.ca/hfd/pubs/docs/Lmh/Lmh31.pdf 
Sepúlveda, S, Serey, A, Lara, M, Pavez, A \& Rebolledo S 2010, Landslides induced by the April 2007 Aysén Fjord earthquake, Chilean Patagonia', Landslides, vol. 7, pp. 483-492.

Serey, A, Piñero-Feliciangeli, L, Sepúlveda, S, Poblete, F, Petley, D \& Murphy, W 2019, 'Landslides induced by the 2010 Chile megathrust earthquake: a comprehensive inventory and correlations with geological and seismic factors', Landslides, vol. 16, pp. 1153-1165.

Shaw, J \& Lintern, D 2016, 'Marine geology, geomorphology of the Kitimat Fiord System, British Columbia, parts of NTS 103-A, NTS 103-H and NTS 103-I', Geological Survey of Canada, Canadian Geoscience Map 275, https://doi.org/10.4095/298793

Shaw, J, Stacey, C, Wu, Y \& Lintern, D 2016, 'Anatomy of the Kitimat fiord system, British Columbia', Geomorphology, vol. 293, pp. 108-129.

Skvortsov, A \& Bornhold, B 2007, 'Numerical simulation of the landslide-generated tsunami in Kitimat Arm, British Columbia, Canada, 27 April 1975', Journal of Geophysical Research, vol. 112, pp. 20-28.

Soil Classification Working Group 1998, The Canadian System of Soil Classification, Agriculture and Agri-Food Canada, Ottawa.

Suleimani, E, Hansen, R \& Haeussler, P 2009, 'Numerical study of tsunami generated by multiple submarine slope failures in Resurrection Bay, Alaska, during the MW 9.21964 Earthquake', Pure and Applied Geophysics, vol. 166, pp. 131-152.

Thomson, R, Fine, I, Krassovski, M, Cherniawsky, J, Conway, K \& Wills, P 2012, Numerical simulation of tsunamis generated by submarine slope failures in Douglas Channel, British Columbia, Canadian Science advisory document, Department of Fisheries and Oceans.

Tinis, S 2015, BC Storm surge forecasting system: 2015-2016 Storm Surge Almanac, 13 pages, http://www.stormsurgebc.ca/files/reports/2015-2016.pdf

Uslu, B, Power, W, Greenslade, D, Eblé, M \& Titov, V 2009, 'The July 15, 2009 Fiordland, New Zealand Tsunami: Real-Time Assessment', Pure and Applied Geophysics, vol. 168, pp. 1963-1972.

Wieczorek, G, Geist, E, Motyka, R \& Jakob, M 2007, 'Hazard assessment of the Tidal Inlet landslide and potential subsequent tsunami, Glacier Bay National Park, Alaska', Landslides, vol. 4, pp. 205-215.

Wegmüller, U, Werner, C, Wiesmann, A \& Frey, O 2019, GAMMA, Version 1.6, computer software, Gamma Remote Sensing, Gumligen, http://www.gamma-rs.ch 